\title{
NEM AUTOR, NEM SOMENTE FUNÇÁO-AUTOR: TAMBÉM SUJEITO-IDEALIZADOR
}

\section{NEITHER AUTHOR, NOT ONLY FUNCTION-AUTHOR: BUT ALSO IDEALIZER-SUBJECT}

\author{
Daiane Siveris* \\ Universidade Federal do Rio Grande do Sul, Programa de Pós-Graduação em \\ Letras, Porto Alegre, RS, Brasil
}

Ana Zandwais

Universidade Federal do Rio Grande do Sul, Instituto de Letras, Programa de Pós-

Graduação em Letras, Porto Alegre, RS, Brasil

Resumo: $\mathrm{O}$ trabalho apresenta o desenvolvimento de uma noçáo proposta em nossa Dissertação, mas não desenvolvida até o momento. Trata-se de função-idealizador. A partir de reflexōes sobre sujeito, função-autor e função-leitor, dentro do Projeto 'História das Ideias', propomos algumas análises sobre constituição, formulação e circulação de sentidos e explicitamos, levando em conta a teoria e as análises, o desenvolvimento de nossas questóes acerca da noção de função-autor.

Palavras-chave: dicionário; Língua Portuguesa; sujeito; função-autor; função-leitor; funçãoidealizador.

Abstract: The paper presents the development of a notion proposed in our master's research but not yet concluded. It is the notion of idealizer-function. From reflections on subjects like function of author and function-of reader, inside the Project 'History of Ideas' we develop some analysis on the constitution, formulation and circulation of senses, considering our questions on the notion of author-function.

Keywords: dictionary; Portuguese Language; function of authorship, function of reader; function of idealizer

\section{Um efeito de início}

Este trabalho visa a apresentar algumas consideraçóes sobre nossa Dissertação, defendida em nível de Mestrado, no ano de 2012, as quais revisitamos na tentativa de explicitar o conceito de função-idealizador anteriormente proposto. Nosso objetivo, no trabalho de Dissertação, era investigar o funcionamento da noção função-autor no Dicionário Contemporâneo da Língua Portuguesa, denominado, no decorrer do

\footnotetext{
* Bolsista CNPq.
} 
trabalho, como DCA (Dicionário Caldas Aulete), levando em consideração o fato de que a autoria de um dicionário também passa pela constituição identitária do sujeito falante da língua.

Em busca de respostas, analisamos os prefácios das oito edições do dicionário, publicado, em sua primeira edição, no século XIX, em Portugal, e tendo sido atualizado no Brasil até a década de 1980. Nesses prefácios, buscamos investigar três questôes específicas: a constituição do dicionário em redes de memória, o funcionamento do dicionário no processo de colonização/descolonização linguística no Brasil e a constituição, formulação e circulação de sentidos no DCA. Essas três questôes contribuíram para compreender o funcionamento da noção função-autor no dicionário, questão central que norteou nossas discussôes.

No trabalho que ora apresentamos, desenvolvido a partir do Projeto 'História das Ideias: relaçôes entre linguagem, cultura e sociedade', buscamos retomar algumas noçóes, especialmente as de sujeito, de funçãoautor e de funçáo-leitor, tal como explorados na Análise do Discurso em articulação com a História das Ideias Linguísticas. Do mesmo modo, apresentaremos alguns recortes que possibilitam explicitar a constituição, a formulaçáo e a circulação de sentidos no DCA, para fins de compreensão do modo como essas noçóes contribuem para entender o funcionamento da função-idealizador, ponto teórico ao qual chegamos na Dissertação e que está em desenvolvimento.

\section{Um sempre retorno à teoria}

Nos estudos discursivos, ao buscar analisar o discurso em instrumentos linguísticos de Língua Portuguesa, tais como o dicionário, pensamos que este seja o lugar onde sujeitos marcam sua posição em determinadas formaçóes discursivas, um espaço em que sujeitos, na sua relação com a língua e a história, tentam unificar/homogeneizar a Língua Portuguesa a partir do imaginário que têm de seus leitores. Além disso, segundo Henry (1997, p. 30), "é enquanto sujeito que qualquer pessoa é 'interpelada' a ocupar um lugar determinado no sistema de produção", ou seja, é por ser, contraditoriamente, livre e submisso que o sujeito assume uma certa posição, determinada ideologicamente - constitutiva das práticas discursivas - e que determina os sentidos na relação entre ideologias dominantes e ideologias dominadas.

${ }^{1}$ O Projeto "História das Ideias" é desenvolvido no Programa de Pós-Graduação em Letras da UFRGS, área de Teorias do Texto e do Discurso. 
Conforme Pêcheux (2009, p. 150),

[...] a interpelação do indivíduo em sujeito de seu discurso se efetua pela identificação (do sujeito) com a formação discursiva que o domina (isto é, na qual ele é constituído como sujeito): essa identificação, fundadora da unidade (imaginária) do sujeito, apóia-se no fato de que os elementos do interdiscurso [...] são re-inscritos no discurso do próprio sujeito.

O sujeito "seleciona no interior da formação discursiva que o domina [...] um enunciado, forma ou sequência" (PÊCHEUX, 2009, p. 161), que está no campo daquilo que poderia reformular o enunciado em determinada formação discursiva, e isso pode ser observado na constituiçáo do dicionário por um sujeito que toma a posiçáo de lexicógrafo. Isso nos remete ao esquecimento número dois, proposto por Michel Pêcheux, ou seja, de que o sujeito tem a ilusão da literalidade do sentido. Dito de outro modo, o sujeito acredita que o sentido só pode ser aquele e náo outro.

Pêcheux (1975), em seu texto "Hacia el análisis automático del discurso", afirma que esse esquecimento caracteriza-se pelo fato de o sujeito redizer seu discurso, formulando e reformulando-o de modo a poder chegar mais perto do sentido que ele deseja que o seu interlocutor atribua ao que ele está dizendo. Por isso, o autor afirma que esse é um funcionamento do tipo "pré-consciente/consciente" (PÊCHEUX, 1975, p. 251). Além de ter essa ilusão, a de controlar o sentido, o sujeito "não pode, por definição, se encontrar no exterior da formação discursiva que o domina" (PÊCHEUX, 2009, p. 161), pois ele também tem a ilusão de que é a fonte de seu dizer, o que caracteriza a eficácia do esquecimento.

Conforme afirma Pêcheux (1975), na medida em que no esquecimento número dois dá-se o funcionamento do discurso de forma pré-consciente/ consciente, no esquecimento número $\mathrm{um}^{2}$ esse funcionamento dá-se de forma inconsciente, pois o sujeito náo tem acesso a essa zona discursiva. É por esse motivo, afirma o autor, que o esquecimento número um é constitutivo da subjetividade na linguagem. Para Michel Pêcheux, o sujeito não é a origem e a fonte de seu dizer e, portanto, não pode haver uma oposição entre objetividade e subjetividade; essa questão destaca o deslocamento da centralidade do sujeito na produção de sentidos, isto é, o fato de que os sentidos são efeitos de esquecimentos e de determinadas condiçôes de produção.

\footnotetext{
${ }^{2}$ Esquecimento número um é o chamado esquecimento ideológico, é a ilusão que o sujeito tem de ser 'o senhor de suas escolhas'.
} 
Esses esquecimentos, por outro lado, contribuem para a compreensão da tomada de posiçáo do sujeito lexicógrafo do dicionário, pois este assume uma posiçáo de sujeito responsável pelo que produz, pelo que consta(rá) no dicionário, um sujeito conhecedor da Língua Portuguesa, uma posiçãosujeito de estudioso da língua que lhe permite que seja determinado o que pode ou não fazer parte do dicionário. $\mathrm{E}$, para que essa posição possa sustentar-se enquanto tal, os esquecimentos número um e número dois devem estar em funcionamento.

Se o esquecimento número dois seria da ordem do pré-conscientel consciente, pois o sujeito, na definição de determinado item lexical, por exemplo, acredita que o sentido só pode ser aquele que ele atribuiu, e não outro, o esquecimento número um intervém permitindo a nós compreendermos a partir de que lugares o sujeito seleciona determinados itens lexicais e passa a defini-los pela intervenção desta ou daquela formação discursiva em seu 'universo lexicológico'. Isso é possível devido ao modo como ele se reconhece como sujeito, à ilusão de que está na origem de seu dizer e de que aquilo que está sendo definido para determinado item lexical é algo original.

A noção de sujeito, compreendida em nosso trabalho, portanto, é a de um lugar, uma posiçáo assumida no discurso, pelo reconhecimento com esta ou aquela formação discursiva em que o sujeito inscreve-se. Assim, concordamos com Orlandi (2005, p. 65) quando afirma que a função-autor "constrói uma relação organizada - em termos de discurso - produzindo um efeito imaginário de unidade". Embora não se tenha um sujeito dono de seu dizer, pois tudo o que é formulado está na ordem do repetível e em algum lugar, em algum momento, já foi dito, toda vez que se tem um efeito imaginário de unidade, isto é, que se tem função-autor, o sujeito é colocado imaginariamente na origem do sentido e é responsabilizado por sua produção (ORLANDI, 2005).

Acrescentamos, em conformidade com Pêcheux (2009), que, se o sujeito tem a ilusão de ser essa origem do dizer e de poder controlar os sentidos, essa ilusão faz-se necessária para que ele possa constituir-se enquanto tal, inscrevendo seu dizer no interdiscurso. Por isso, podemos afirmar que investigar o funcionamento da funçáo-autor nos prefácios das diferentes ediçôes do DCA possibilitou compreender as relaçóes que os sujeitos estabelecem com a língua, que discursos produzem, as formas como são feitos recortes para a elaboraçáo/reelaboração do dicionário, bem como quais são as condiçóes sócio-históricas e ideológicas em que se insere determinado instrumento linguístico. 
Retomando as noçôes de sujeito e de função-autor, constatamos que, no texto "O que é um autor?", Foucault (1992) apresenta tais noçóes em sua relação com o texto, com a obra de um determinado autor. Quanto à noçáo de obra, Foucault afirma que esta "que tinha o dever de conferir a imortalidade passou a ter o direito de matar, de ser a assassina de seu autor" (FOUCAULT, 1992, p. 36), ou seja, a obra, assim como a escrita, estaria relacionada ao apagamento da singularidade do sujeito que escreve. Com relação à escrita, ele pontua que é um jogo de signos ordenado, mas cuja regularidade está sempre a ser experimentada nos seus limites, pois ela vai

[...] além das suas regras, desse modo as extravasando. Na escrita, não se trata da manifestação ou da exaltação do gesto de escrever, nem da fixaçáo de um sujeito numa linguagem: é uma questão de abertura de um espaço onde o sujeito de escrita está sempre a desaparecer (FOUCAULT, 1992, p. 35).

O referido autor trabalha o nome de autor como um nome próprio, ou seja, o nome próprio remetendo ao sujeito individual, empírico. O nome de autor, por sua vez, asseguraria uma função indicadora e classificatória e esta possibilitaria agrupar certos textos, delimitá-los, selecioná-los, criando um efeito de unidade.

Entendemos que, para Foucault (1992), a função do nome de autor seria equivalente à função de paternidade, pois possibilitaria caracterizar o discurso e, a partir daí, a possibilidade de agrupar certos textos sob a rubrica de um mesmo nome. Entretanto, o nome de autor não transita, como o nome próprio, do interior de um discurso para o indivíduo real e exterior. O nome próprio remete ao indivíduo empírico, e o nome de autor bordeja os textos, recorta-os, delimita-os, caracteriza-os (FOUCAULT, 1992, p. 45). Deste modo, nome próprio e nome de autor podem remeter para referências distintas.

Em outro texto, "A ordem do discurso", Foucault (2001, p. 27-28) afirma que "pede-se que o autor preste contas da unidade de texto posta sob seu nome; pede-se-lhe que revele, ou ao menos sustente, o sentido oculto que os atravessa, pede-se-lhe que os articule com sua vida pessoal e suas experiências vividas". Entretanto, para Foucault (2001), ainda que haja uma soma de textos que possam ser atribuídos a um nome próprio, esses textos não são homogêneos. Podem ter sido publicados sob pseudônimo, constituírem conjuntos de anotaçóes, rascunhos, escritos revelados post-mortem, ou ainda terem sido simplesmente publicados com seu nome. Tomado de uma forma simplista, o autor estaria limitado a um sujeito empírico, a um jogo de 
identidade, de individualidade, ao mesmo tempo em que é responsabilizado pelo efeito de unidade do texto por ele produzido.

Por tais razóes, em nosso trabalho, buscou-se compreender e explicitar o autor como sendo uma função e/ou posição discursiva que o sujeito assume ao produzir o discurso. Com a noção de função-autor, portanto, concebe-se o discurso enquanto produçáo de efeitos de sentidos determinados pela ação da ideologia e sob o atravessamento do inconsciente.

Orlandi (2006), ao discutir a noção de autoria em sua obra Discurso e Leitura, aponta para uma funçáo enunciativa do sujeito. Ela afirma, a partir do que aponta Foucault (2001), que o autor é o princípio de agrupamento do discurso, com sua unidade, origem e coerência. Pensar essa unidade, que se constitui a partir da heterogeneidade, leva às funçóes enunciativas do sujeito. Primeiro, o locutor, ou seja, aquele que se coloca como eu no discurso; por segundo, o enunciador, isto é, a perspectiva que o eu constrói; e, por último, o autor, que é a função social que o eu assume enquanto produtor de linguagem e de sentidos. Com isso, a autora explicita que é esta, a terceira categoria de sujeito, a mais afetada pela exterioridade e dá-se pela exigência de efeitos de clareza, de começo, meio e fim do texto.

Em Análise de Discurso: princípios e procedimentos, a autora desloca a noçáo de autoria defendida por Foucault (2001), ou seja, de que há discursos que precisam de quem os assine, mas não de autores, e afirma que "um texto pode até não ter um autor específico, mas, pela função-autor, sempre se imputa uma autoria a ele" (ORLANDI, 2005a, p. 75).

Assim, em todo e qualquer discurso há um sujeito que se mostra, que se marca e que marca também a sua posiçáo. E isso náo está diretamente ligado a um nome próprio, mas a uma tomada de posiçáo do sujeito na produção do discurso. Ademais, ela afirma que o "sujeito está para o discurso assim como o autor está para o texto" (ORLANDI, 2005a, p. 73). O sujeito resulta da interpelaçáo do indivíduo pela ideologia, e a função-autor, por sua vez, representa um efeito de unidade e é uma função necessária ao texto.

Entretanto, diferente da obra anteriormente citada - Discurso e Leitura -, neste texto - Análise de Discurso: princípios e procedimentos -, a autora trata da autoria como uma funçáo do sujeito e da funçáo-autor como uma função discursiva do sujeito, sempre relacionada à função-leitor. Ambos, funçáa-autor e função-leitor, constituindo-se simultaneamente, pois, para que se tenha uma função-autor constituída, é necessário ter seu duplo, que é a função-leitor.

O princípio da autoria seria sempre algo necessário para qualquer discurso, enquanto colocado na origem da textualidade. A função-autor 
enquanto função discursiva do sujeito, por sua vez, é determinada pela exterioridade, pois é a função que o eu assume enquanto produtor de linguagem, de texto. E sob esta ótica, ela se aproxima de Michel Foucault.

Em seu texto Discurso e Texto: formulaçáo e circulaçáo dos sentidos, Orlandi (2005) trata a função-autor por seu duplo no efeitoleitor. Isso acontece pelo mecanismo de antecipação, pelo qual a funçãoautor projeta-se imaginariamente no lugar em que o outro o escuta/lê. Esse imaginário constitui um leitor virtual que lhe corresponde.

A função-leitor constitui-se, na relação com a linguagem, em funçáo da materialidade textual já trazer em si um efeito-leitor que é produzido pelos gestos de interpretaçáo de quem o produziu, pela resistência material da textualidade e pela memória do sujeito que lê (ORLANDI, 2005). Isso acontece porque a textualidade é feita de gestos de interpretação, sejam estes do sujeito-autor ou do sujeito-leitor, "um está sempre exposto ao olhar do outro". O que se designa texto é efeito da discursividade, mesmo que esta seja permeada por faltas, falhas, lacunas, equívocos.

Conforme a autora (ORLANDI, 2005, p. 65-66), "se temos, de um lado, a função-autor como unidade de sentido formulado, em função de uma imagem de leitor virtual, temos, de outro, o efeito-leitor como unidade (imaginária) de um sentido lido". A partir disso, podemos afirmar que função-autor e efeito-leitor mostram que os sentidos são múltiplos, dispersos e descontínuos no discurso.

Ao lermos um texto, diferentes sentidos são possíveis, pois ele tem pontos de deriva e de deslizamentos que possibilitam diferentes interpretaçóes. Fala-se de efeito-leitor, porque este resulta de confrontos e de movimentos de entrega e de recusa frente à materialidade do texto em decorrência da memória e das condições de produção do discurso (ORLANDI, 2005). Se pensarmos que o sentido sempre pode ser outro, na relação entre funçãoautor e efeito-leitor, teríamos "um sentido no meio de outros" (ORLANDI, 2005 , p. 66), pois o efeito-leitor dá-se no reconhecimento de uma leitura no meio de outras.

Nunes (1994, p. 41) afirma que, quando se fala da função-leitor, busca-se explicitar as formaçóes imaginárias que permitem a construção dessa noção. Para isso, descreve-se "a 'posição' discursiva do leitor em determinadas conjunturas, e isso depende apenas relativamente da atribuição de um leitor virtual no ato da escrita”. A construção de um leitor virtual pode ser considerada um dos fatores que interferem na constituição da posição de função-leitor, pois não a tomamos como um interlocutor, mas como a função do outro na leitura, constituído historicamente pelo 
atravessamento de saberes das formaçôes discursivas em que se inscreve.

Além disso, acrescentando o que afirma Pêcheux (2009) em torno do discurso, pode-se pontuar que toda prática discursiva do sujeito está inscrita em uma formação discursiva, a qual caracteriza a instância ideológica em um tempo e época determinados. Desse modo, toda prática discursiva resulta de sujeitos, pois "não existe prática sem sujeito" (PÊCHEUX, 2009, p. 197). Assim,

[...] todo sujeito é constitutivamente colocado como autor de e responsável por seus atos em cada prática em que se inscreve; e isso pela determinação do complexo das formaçóes ideológicas (e, em particular, das formaçôes discursivas) no qual ele é interpelado em 'sujeito-responsável (PÊCHEUX, 2009, p. 198).

A função-autor realiza-se quando há um sujeito que toma a posição de produtor da linguagem, produzindo um efeito imaginário de unidade, começo, meio e fim (ORLANDI, 2005). Desse modo, a funçáo-autor é afetada pela história e inscreve-se em determinada formação discursiva para produzir um discurso interpretável. Toda vez que isso acontece, ou seja, toda vez que o sujeito produz um discurso, ele está inscrevendo esse discurso (formulação) no interdiscurso (constituição).

No trabalho que desenvolvemos, a função-leitor configura-se como a função do outro na leitura. Pêcheux (2006, p. 54) afirma que

[...] é porque há o outro nas sociedades e na história, correspondente a esse outro próprio ao linguajeiro discursivo, que aí pode haver ligação, identificação ou transferência, isto é, existência de uma relaçáo abrindo a possibilidade de interpretar. E é porque há essa ligação que as filiaçōes históricas podem-se organizar em memórias, e as relaçóes sociais em redes de significantes.

A interpretação instaura-se com a existência de um outro na sociedade: a função-leitor. A funçáo-autor, pelo mecanismo de antecipação, projeta um outro que é a função-leitor. Essa projeção é o que possibilita a emergência de sentidos na leitura (interpretação) de uma materialidade, pois entram em funcionamento a memória do sujeito-autor e a do sujeito-leitor, as filiaçóes históricas de cada um desses sujeitos, bem como as práticas sociais com as quais cada um se identifica na produção do discurso.

Nossa proposta de pesquisa trata, entretanto, além de função-autor e função-leitor, da função de sujeito-idealizador. Contudo, torna-se mister 
explicitar as análises, ainda que breves e retomadas de nossa Dissertação, para fins de compreender como chegamos à função-idealizador, noção esta importante e que acreditamos ter respondido a alguns de nossos questionamentos acerca do trabalho de autoria no dicionário.

\section{Por uma relação entre teoria e análise}

Nesta parte de nosso trabalho, trazemos para reflexão alguns recortes discursivos, retomados de trabalho anterior (SIVERIS, 2012), que possibilitam a análise do imaginário de função-autor e de função-leitor, o qual também contribui para compreender o espaço de circulação do instrumento linguístico analisado, bem como quem ou o que representa a função-autor no DCA.

Ao buscar compreender esse espaço de circulação, encontramos em Orlandi (2008) o que se entende por constituição, formulação e circulação. No processo de constituição dos sentidos, conforme a autora, temos o trabalho da memória (interdiscurso), a interpelação do indivíduo em sujeito, a constituição de sua forma histórica e os efeitos que produz a partir de sua posição-sujeito; no processo de formulação, temos a relação do discurso com o texto que atualiza a memória, a individua(liza)ção do sujeito pela sua função-autor; na circulação, temos o funcionamento das circunstâncias de enunciação e a experiência de mundo como elementos desencadeadores e os sujeitos sociais que assumem a função-autor em seus percursos, nos diferentes lugares (ORLANDI, 2008). Esses três processos funcionam simultaneamente e tanto o sujeito como o sentido são afetados por eles. Um sentido é determinado pela sua constituição, pela formulação e pelo modo como circula (ORLANDI, 2008). O sujeito, em sua posiçâo de função-autor, é afetado pelo lugar em que se constitui e do qual fala.

Em nossa pesquisa (2012), propomos uma fundição entre a funçãoidealizador $^{3}$ e a funçáo-autor. Pode-se pensar, além disso, na equipe de sujeitos lexicógrafos (e dicionaristas) que produz um dicionário e não tem a autoria revelada empiricamente com nomes, embora o instrumento linguístico como um todo sempre seja da responsabilidade de Caldas Aulete, o idealizador, pelo fato da relação que se estabelece com o sujeito-leitor.

O sujeito-autor, por meio da individua(liza)ção pelo Estado, é colocado como responsável pelo discurso produzido no DCA, pois se institui um lugar, responsabilizando-se um nome instituído - o de Caldas

\footnotetext{
${ }^{3}$ Na próxima seção, explicitaremos em pormenores o que entendemos por esse conceito.
} 
Aulete. A inscrição do nome desse sujeito no dicionário, conforme se pode observar, dá-se para representar qualquer erro ou deficiência que nele possa haver ${ }^{4}$. Logo, a Caldas Aulete compete a posição de sujeito-autor, sujeito responsável pela produçáo do dicionário e sujeito que se responsabiliza por qualquer erro ou equívoco que o dicionário possa conter, na medida em que o lugar instituído necessita de legitimação para que o dicionário possa ser publicado e para que possa circular na sociedade enquanto importante instrumento de consulta e de normatizaçáo da Língua Portuguesa.

Esse sujeito que toma a posição de função-autor seleciona, a partir do interdiscurso, determinados dizeres que passam a constituir seu discurso. Esses dizeres são linearizados e atualizados, por sua vez, no intradiscurso. Quando passam a circular, os dizeres são determinados pelas instâncias discursivas, ou seja, são determinados pelas condiçôes sócio-históricas em que se inscrevem os sujeitos.

$\mathrm{Na}$ tentativa de ilustrar o que temos apresentado até o momento em relação à função-autor e à funçáo-leitor, destacamos um ponto que é recorrente nos textos prefaciais, tanto nas ediçôes portuguesas quanto nas ediçôes brasileiras, e que constitui nossos recortes discursivos:

\section{RD1 = provincias de Portugal, dos Estados do Brasil; \\ $\mathrm{RD} 2$ = ponto de vista brasileiro e português; \\ RD3 = homens mais eminentes portuguezes e brazileiros. ${ }^{5}$}

Ambos os recortes destacam a relação entre Brasil e Portugal, mas gostaríamos de ressaltar a ordem em que aparecem os termos: no RD1, o qual se refere à segunda edição portuguesa, assim como no RD3, referente à primeira edição portuguesa, os termos Portugal e portuguezes são indicados antes dos termos Brasil e brazileiros. No RD2, por sua vez, o qual diz respeito às ediçóes brasileiras, observamos uma alteração na ordem: antes aparece brasileiro para posteriormente destacar-se o termo português.

Além disso, províncias de Portugal remete à unidade, ao sentido de pertencimento dessas províncias ao reino de Portugal; Estados do Brasil, por sua vez, caracteriza-se pela fragmentação, toma-se as partes pelo todo, o que constitui o processo metonímico. A partir dessas observaçóes, alguns questionamentos surgem: que funcionamento político tem-se

${ }^{4}$ Constitui parte do recorte que realizamos da $1^{\text {a }}$ ediçáa portuguesa, como veremos mais adiante.

${ }^{5}$ Grifos nossos. 
com essa ordem dos termos? Que imaginário de função-autor projeta-se? Que imaginário de funçâa-leitor daí se depreende? Como explicitar essas alteraçóes de um território a outro ao se publicar um dicionário em Portugal e posteriormente atualizá-lo no Brasil?

Analisando e interpretando os recortes discursivos, chegamos ao seguinte ponto: as ediçốes portuguesas visam a disponibilizar um dicionário que possa servir de instrumento de consulta a todos os sujeitos falantes de Língua Portuguesa, independentemente de serem sujeitos habitantes de Portugal ou dos demais territórios que se caracterizam como ex-colônias da metrópole portuguesa. Já as ediçóes brasileiras visam a um público mais específico inicialmente, os habitantes do Brasil, para posteriormente se dirigirem aos demais falantes de Língua Portuguesa.

Entende-se que há uma diferença na tomada de posição de sujeito quando se trata de autoria do DCA no Brasil; o sujeito-autor, ao assumir sua posição de função-autor, tem seu duplo no sujeito-leitor, na função-leitor (ORLANDI, 2005), pois, na publicação das ediçóes portuguesas, ao se dirigir aos portugueses, o sujeito-autor refere-se primeiro a estes para depois dirigir-se aos brasileiros. Nas ediçóes brasileiras, por sua vez, o sujeito-leitor brasileiro é interpelado inicialmente para posteriormente fazer referência ao sujeito-leitor português.

É pelo mecanismo de antecipação (ORLANDI, 2005) que a funçãoautor das ediçóes portuguesas projeta imaginariamente um leitor virtual português, um leitor que conhece a Língua Portuguesa e que pode precisar de um instrumento linguístico para consultar. $\mathrm{O}$ mesmo dá-se com a funçãoautor das ediçôes brasileiras. Ao determinar uma ordem para apresentar os termos - brasileiro e português - e não o inverso, mostra-se que a produção de sentidos estabelece-se nessa relação identitária entre função-autor e função-leitor, determinada pelas condiçóes de produção dos discursos, bem como pelas conjunturas histórico-sociais em que se inscrevem os sujeitos.

Aí se tem o político funcionando, através de uma negociação de ordem das estruturas e dos efeitos de sentidos entre função-autor e funçãoleitor; negociação de sentidos essa que possibilita que, ao alterar-se a ordem dos termos, determinem-se as formas de reconhecimento ideológico mútuo entre função-autor e função-leitor. E é isso que caracteriza a constituição, a formulação e a circulação dos sentidos que apontamos no início desta parte do texto.

Ainda sobre esses recortes discursivos, outro ponto importante a destacar é o emprego da conjunção aditiva $e$. Questionamo-nos sobre qual a sua contribuição no processo de constituição desse discurso. Sob o viés da 
gramática, buscamos em Bechara (2010) o suporte teórico necessário para abordar essa questáo. Segundo o autor, a conjunção aditiva indica que "as unidades que unem (palavras, grupos de palavras e oraçóes) estão marcadas por uma relação de adição" (BECHARA, 2010, p. 322). Entretanto, a nosso ver, o funcionamento da conjunção aditiva nos recortes em análise dá-se de forma diferente, embora continue sendo uma conjunção aditiva. Ancorados no que afirma Bechara (2010), compreendemos que, mesmo gramaticalmente o $e$ sendo uma conjunçáo aditiva, semanticamente não haveria, nesse caso, a soma de ideias, mas a oposição, pois, segundo Bechara (2010, p. 322),

[...] graças ao significado dos lexemas envolvidos na adição, o grupo das unidades coordenadas permite-nos extrair um conteúdo suplementar de 'causa', 'consequência', 'oposição', etc. Estes sentidos contextuais, importantes na interpretação do texto, nâo interessam nem modificam a relação aditiva das unidades envolvidas.

Então, brasileiro $\boldsymbol{e}$ português, portuguezes $\boldsymbol{e}$ brazileiros, unemse por uma relação gramatical de adição, embora a oposição semântica existente entre eles, ainda que apresentando, conforme Bechara, um sentido suplementar ${ }^{6}$, seja fundamental para que se compreenda que "a ordem dos fatores altera o produto"'. E qual a contribuição da funçáo-autor no processo de constituição desse discurso dicionarístico?

O sujeito que toma a posição discursiva de funçáo-autor sob as condiçóes sócio-históricas portuguesas projeta seu leitor virtual. Esse sujeito, em sua posição de função-autor, imaginariamente constitui seu duplo, a funçáo-leitor, que é de nacionalidade portuguesa, tendo em vista que o dicionário como um todo é publicado para falantes de Língua Portuguesa em geral, mas é constituído, formulado e circula primeiro em Portugal para depois ser acessível também no Brasil.

O mesmo ocorre com as publicaçóes das ediçóes brasileiras, pois o imaginário de função-leitor que se tem é de um sujeito brasileiro e não mais português, inicialmente.

Outro importante ponto a ser destacado refere-se à seleção lexical feita no texto prefacial da primeira edição do dicionário em que o sujeito, na posição discursiva de função-autor, agradece o apoio que recebeu, para

\footnotetext{
${ }^{6}$ Cf. Bechara (2010). Observamos que as consideraçóes de Bechara encontram seus limites nos aspectos sintáticos, já que, para o autor, o que é de ordem contextual é suplementar e não modifica uma relação classificatória de base sintática.
} 
elaborar o dicionário, tanto de sujeitos portugueses quanto brasileiros, o que apontaria para a coletividade da produçáo do dicionário. Vejamos:

RD4 = Coadjuvaçáo valiosissima e honrada que elle recebeu dos homens mais eminentes portuguezes e brazileiros que nos coadjuvaram, servindo apenas a inserção do nosso nome n'este livro para representar qualquer erro ou deficiência que n'elle possa haver. ${ }^{7}$

O que se pode compreender a partir dessa reiteração do termo coadjuvar? Para explicitar esse funcionamento, buscamos em Houaiss (2009) a definição desses termos:

Coadjuvação = ato ou efeito de coadjuvar, colaboração, cooperação, auxílio. Coadjuvar = prestar auxílio(a), ajudar(-se), auxiliar(-se).

A partir dessas definiçóes dadas ao verbete, entendemos que o sujeitoautor busca explicitar que os brasileiros e os portugueses, que contribuíram com a produção do dicionário, não apenas forneciam os termos de um ou outro território, mas também participaram da elaboração, da definição e da explicitaçáo dos sentidos de cada termo, no sentido de cooperaçáo, dado na definição do verbete coadjuvação.

Retomando, ainda, na esteira das consideraçôes sobre função-autor e funçáo-leitor, entendemos que, se, por um lado, temos a função-autor, por outro, emerge a função-leitor na relação que este estabelece com aquele. Observemos o seguinte recorte discursivo:

RD5 = Os diccionarios colligidos por tal plano são principalmente destinados áquelles que se dedicam á profissão das letras, e nós dirigimo-nos em geral a todos que necessitam de consultar o lexicon da lingua, para resolver alguma d'essas difficuldades philologicas que frequentemente surgem sobre a orthographia, pronunciação, significação ou emprego syntactico de um ou de outro termo. ${ }^{8}$

\footnotetext{
${ }^{7} 1^{\text {a }}$ edição -1881 . Grifos nossos.

${ }^{8}$ Esse recorte é parte constitutiva do texto prefacial denominado "Plano", presente na 1a edição portuguesa do dicionário (1881), no qual o sujeito-autor explicita a importância da obra e projeta seu leitor virtual.
} 
Neste RD5, o sujeito-autor, pelo complexo das formações imaginárias de que trata Pêcheux (1997), antecipa seu leitor, projeta uma imagem dele. É isso que acontece também nos RD2 e no RD3, conforme já apresentamos; o sujeito-autor altera a ordem dos vocábulos - brasileiro e português - na medida em que se dirige a um ou a outro, tendo em vista o espaço de circulação do dicionário. No RD5, observamos que a imagem do sujeito-leitor dos demais dicionários é a de um público específico - os que se dedicam à profissão das letras, e que o sujeito-autor quer uma interlocução também com um "público geral", a massa "leiga", falantes (ou não) de Língua Portuguesa, mas que a compreendem - todos os que necessitam consultar o léxico da língua.

\section{Sujeito-idealizador: outra leitura possível}

Para tratar do conceito de sujeito-idealizador que propomos em trabalho anterior (SIVERIS, 2012), bem como na tentativa de melhor explicitar essa noção, trazemos, de imediato, um recorte discursivo que auxiliará nas nossas reflexôes sobre esse ponto.

RD6 = Por todos estes atributos temos a consciência de apresentar ao público uma obra digna do nome de quem a planeou - F. J. de Caldas Aulete - e de contribuir, como é missão do editor, para o prestígio da cultura nacional. ${ }^{9}$

Planear, que corresponde a planejar, tem sentido diferente de elaborar, pensando especificamente no plano de uma obra e sua realização/elaboração. Segundo Houaiss (2009), planejar pode corresponder a "elaborar o plano ou a planta de; projetar; organizar plano ou roteiro de; programar; ter a intenção de; tencionar". Elaborar, por sua vez, tem as acepçóes de "preparar laboriosa e paulatinamente; realizar, organizar, geralmente com grande cuidado; tornar mais complexo" (HOUAISS, 2009). Embora, referente ao verbete planejar, esteja presente o termo elaborar na própria definição, não consideramos como mesmo sentido porque estamos referindo-nos ao plano da obra, ou seja, ao seu projeto, bem como à elaboração do dicionário, isto é, ao cumprimento deste projeto, à sua realização. É fundamental ressaltar, por outro lado, que este planejamento não se restringe à missão de difundir os significados do léxico, através dos verbetes, mas também de fortalecer,

${ }^{9}$ 3a edição - 1948. 
através do trabalho lexicográfico, a cultura nacional, isto é, as práticas sociais dos sujeitos inseridos na sociedade portuguesa. $\mathrm{O}$ fortalecimento da cultura nacional dá-se muito fortemente no trabalho da/na/sobre a língua, não enquanto seleção do léxico somente, mas também por meio da significação de práticas presentes em Portugal, as quais determinam o lugar das colônias e das ex-colônias portuguesas e também o da metrópole, que mantém aquelas sob seu jugo, não mais econômico, mas linguístico, a partir do momento em que é produzido um dicionário em Portugal para todos os falantes de Língua Portuguesa.

Conforme se observa no RD6, o planejamento, o plano de elaboração do dicionário é de Caldas Aulete ${ }^{10}$, embora este tenha falecido antes mesmo da concretização do projeto. Assim, qual o funcionamento da função-autor no dicionário se o sujeito a quem é atribuída a autoria não participou da elaboração do instrumento linguístico? Estaria a função-autor relacionada, nesse caso, exclusivamente ao plano do individual ou à imagem de um projeto coletivo ao qual se agrega uma autoria e se sedimenta em um nome? Nossa reflexão aponta para o fato de que o nome de Caldas Aulete estaria relacionado ao dicionário, desde a primeira até a última edição, por ter elaborado o plano e também porque estaria relacionado a isso o processo de individua(liza)ção do sujeito, de que fala Orlandi (2002).

Conforme a autora, esse processo caracteriza-se por dois momentos. No primeiro, tem-se a "interpelação do indivíduo em sujeito pela ideologia" (ORLANDI, 2002, p. 71), ou seja, éo passo para que o indivíduo, afetado pelo simbólico, na história, seja sujeito e subjetive-se. Nesse caso, a subjetivação está ligada ao fazer lexicográfico. A forma-sujeito resultante desse processo de interpelação do indivíduo em sujeito é a forma-sujeito histórica, que se traduz pelos verbetes, pelas formas de atribuição de significados aos itens lexicais e pelos acentos ideológicos conferidos às palavras.

Assim, o segundo momento do processo que é a "individua(liza)ção do sujeito em relação ao Estado" (ORLANDI, 2002, p. 71) é necessário e pode-se materializar através das instituiçôes. Neste processo, o Estado, por meio de suas instituiçôes, individualiza a forma-sujeito histórica que será livre e responsável e passará a responder como sujeito jurídico, portador de direitos e deveres (ORLANDI, 2002). Atribuir a autoria a Caldas Aulete é responsabilizar, pela unidade da elaboração/produção/publicação de um instrumento linguístico, um sujeito que apenas planeja a obra, na tentativa de dar ao dicionário um estatuto de unidade, de instrumento linguístico que

${ }^{10}$ Caldas Aulete, enquanto sujeito empírico, faleceu em 1878, e a primeira edição do dicionário analisado data do ano de 1881. 
preserva a tradição de seu idealizador.

A partir dessas questôes pontuadas, trazemos uma nomenclatura diferente da já proposta por Orlandi (2005), quando trabalha a noção de função-autor; trata-se da noção função-idealizador. Inicialmente, recorremos a Houaiss (2009) para explicitar o que corresponde ao termo idealizador:

\section{Idealizador:}

(adjetivo e substantivo masculino) - que ou o que idealiza

Essa primeira definiçáo leva-nos a buscar outro termo, em um processo de palavra-puxa-palavra ${ }^{11}$, para compreender o sentido do termo idealizador.

\section{Idealizar:}

1 (transitivo direto e pronominal)- imaginar(-se) de maneira ideal; 2 (transitivo direto e bitransitivo) - criar na imaginação; fantasiar, imaginar, idear;

3 (transitivo direto) - fazer o plano ou a planta de; planejar, projetar, idear.

Nossa observação volta-se ao termo idealizador, bem como à terceira acepção do verbo idealizar, enquanto verbo transitivo direto, em virtude da própria construção frasal do dicionário em análise, qual seja, "obra digna do nome de quem a planeou". O verbo planear é transitivo direto, o objeto direto está anteposto "a", referindo-se à "obra". Se estivesse na ordem direta, teríamos "... de quem planejou ela". "Ela" remetendo ao termo "obra".

A noção de idealizador, na nossa compreensão, está mais relacionada com a função que antecede a autoria mesmo e que depois pode ser tomada como uma forma sinônima; como se o que foi função-idealizador passasse a ser tomado como função-autor e isso continuasse a se reproduzir indefinidamente, sem fazer distinçáo entre um e outro. Daí a proposta de fundição entre função-idealizador e função-autor que mencionamos anteriormente.

A partir desse sujeito idealizador, produz-se o efeito de autoria, a função-autor a nosso ver; é com o sujeito Caldas Aulete (que planeja/idealiza a obra, mas não participa da elaboração) que o sujeito-leitor relaciona-se;

${ }^{11}$ SILVA, Mariza Vieira da. O dicionário e o processo de identificação do sujeito analfabeto. In: GUIMARÃES, Eduardo; ORLANDI, Eni Puccinelli. (Org.) Língua e cidadania: o português no Brasil. Campinas: Pontes, 1996. 
é nele, nesse sujeito-idealizador da obra, que se estabelece a relação de confiança, pois este é um sujeito conhecido/reconhecido, um renomado lexicógrafo português, escritor, político, jornalista, professor e conhecedor da Língua Portuguesa. É nesse sentido que propomos uma investigaçáo, um cotejamento entre a função-autor e a função-idealizador, considerando que, em cem anos de produção dicionarística, a segunda noção - a funçãoidealizador - funde-se e confunde-se com a primeira - a função-autor.

Todavia, sabemos que muito ainda pode, deve e necessita ser trabalhado para avançar na compreensão dessa outra leitura que vimos propondo e entendemos também que muito ainda precisa ser lido, discutido, compreendido e analisado para fins de explicitar esse funcionamento. A nosso ver, temos aí um sujeito-autor que se funde com o sujeito-idealizador. Esse sujeito-autor assumiria uma função discursiva, que é a de função-autor, que se confunde com a de função-idealizador, pois é por meio dessa posição, de função-autor - e também de função-idealizador - que se estabelece a relação com o sujeito-leitor e, consequentemente, com a função-leitor, pois, assim como a funçáo-autor é uma função discursiva do sujeito, a funçãoleitor também é. Entretanto, ao explicitar essas relaçóes, não temos respostas definitivas (se é possível dizer que um dia as teremos enquanto tal), e as leituras seguem nesse caminho de cujo destino não se tem certeza. Contudo, por ora, é o que há.

\section{Referências}

BECHARA, Evanildo. Gramática Escolar da Língua Portuguesa. 2. ed. Rio de Janeiro: Nova Fronteira, 2010.

FOUCAULT, Michel. O que é um autor? 3. ed. Tradução António Cascais e Eduardo Cordeiro. Editora Passagens, 1992.

A ordem do discurso. 7. ed. Tradução Laura F. de A. Sampaio. São Paulo: Loyola, 2001.

HENRY, Paul. Os fundamentos teóricos da "Análise Automática do Discurso" de Michel Pêcheux. In: GADET, Françoise; HAK, Tony (Org.) Por uma análise automática do discurso: uma introdução à obra de Michel Pêcheux. 3. ed. Tradução Bethania Mariani et al. Campinas: Unicamp, 1997. 
HOUAISS, Antônio. Dicionário eletrônico Houaiss da língua portuguesa. 3. ed. Rio de Janeiro: Objetiva, 2009.

NUNES, José Horta. Formaçáo do leitor brasileiro: imaginário da leitura no Brasil Colonial. Campinas: Unicamp, 1994.

ORLANDI, Eni. Língua e conhecimento lingüístico: para uma história das idéias no Brasil. São Paulo: Cortez, 2002.

. Discurso e Texto: formulação e circulação dos sentidos. 2. ed. Campinas: Pontes, 2005.

Análise de Discurso: princípios e procedimentos. 6. ed. Campinas: Pontes, 2005a.

. Discurso e leitura. 7. ed. São Paulo: Cortez, 2006.

. Silêncios: presença e ausência. 2008. Disponível em: $<$ http://www. comciencia.br/comciencia $/$ handler. php? section $=8$ \&edicao $=38 \&$ id $=456>$. Acesso em 26 de outubro de 2013.

PÊCHEUX, Michel. Hacia el análisis automático del discurso. Madrid: Gredos, 1975.

Análise Automática do Discurso (AAD - 69). In: GADET, Françoise; HAK, Tony (Org.) Por uma análise automática do discurso: uma introdução à obra de Michel Pêcheux. 3. ed. Tradução Bethania Mariani et al. Campinas: Unicamp, 1997.

. O discurso: estrutura ou acontecimento. 4. ed. Tradução Eni Puccinelli Orlandi. Campinas: Pontes, 2006.

. Semântica e Discurso: uma crítica à afirmação do óbvio. 4. ed. Tradução Eni Puccinelli Orlandi et al. Campinas: Unicamp, 2009.

SILVA, Mariza Vieira da. O dicionário e o processo de identificação do sujeito analfabeto. In: GUIMARÃES, Eduardo; ORLANDI, Eni Puccinelli (Org.). Língua e cidadania: o português no Brasil. Campinas: Pontes, 1996.

SIVERIS, Daiane. Língua, sujeito e história: implicações da noção funçãoautor na produção dicionarística de Caldas Aulete. 2012. Dissertação (Mestrado em Letras) - Universidade Federal de Santa Maria, Santa Maria, 2012. 
ZANDWAIS, Ana. História das Idéias: diálogos entre linguagem, cultura e sociedade. Porto Alegre: Programa de Pós-Graduação em Letras, 2014. Projeto de pesquisa.

Daiane Siveris - daiasiveris@gmail.com Ana Zandwais - zand@ufrgs.br

Artigo recebido em 12 de dezembro de 2014 e aceito em 16 de janeiro de 2015. 